ア之ノ酸の界面活性さ吸着こに就て

農學士伊藤武男

(昭和五年一月十二日受理)

E. Abderhalden 及 Fodor ${ }^{1}$ はアミノ酸及びポリぺプチードの骨炭による四着 に關する研然に於て此等の物質の吸着は Freundlich の Adsorptionsisothermeに よりて表され得れごも濃度小なる範圍に於ては Henry の定律に從ふ等のことを 確め該吸着は純物理的現像におらすして䕓乃化學漞和力 (Chemischen Kräften)に 歸す可しとせb

余はアミノ酸の界面活性（Oberflächenaktivität) こ吸着この間にも他の例へば 脂肪酸の如き界面活性踾に於けるこ同樣の關係が存するやを知らむこして本研究 をなしたる結果その事需なるここを確め得たり

倘前記雨民の指摘せるノミ.酸の吸着と $\mathrm{H}^{+}$又は $\mathrm{OH}^{-}$イオンさの關係に就て は远めて報告へし

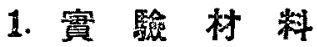

本研究に使用せるガクコ、ル及びアラニンは絹系屑（グリコ、ルの一部はゼラ

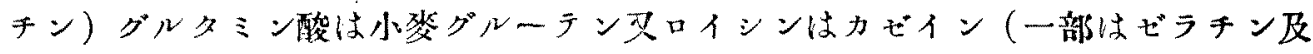

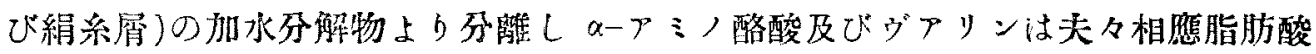
より合成せるものにしてアスパラギン酸はメルク製楒なりき

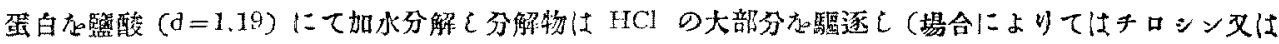

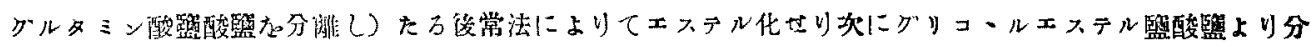

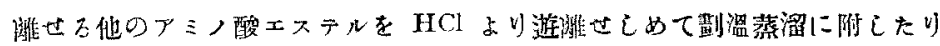

$\begin{array}{ccc}\text { 區 } & \text { 分 } & \text { 溫度 (外浴) } \\ 1 . & \left.50^{\circ} \mathrm{C} \text { ( } \mathrm{mm} . \mathrm{Hg}\right) \\ 2 . & 50 \sim 100^{\circ} \mathrm{C} & 15 \\ 3 . & 100 \sim 120^{\circ} \mathrm{C} & \prime \prime \\ 4 . & \text { 殘 渣 } & \prime \prime\end{array}$

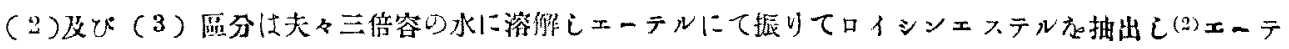

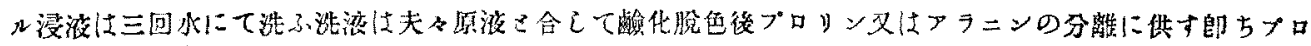

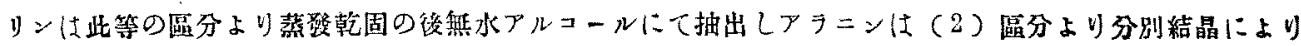




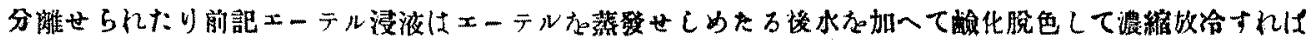
ロイシンな析出せり

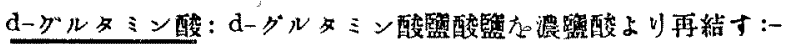

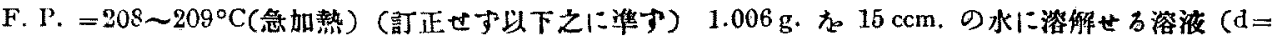
1.0225) D旋光度 $[\alpha]_{\mathrm{D}}=+20 .{ }^{\circ} 57$

分 析： $\mathrm{Cl}=$ (1) $19.05 \% ，(2) 18.94 \%$ 平均 $18.99 \%$

計算数: $\quad \mathrm{C}_{5} \mathrm{H}_{10} \mathrm{O}_{4} \mathrm{NCl}$ ¿して $\mathrm{Cl}=19.32 \%$

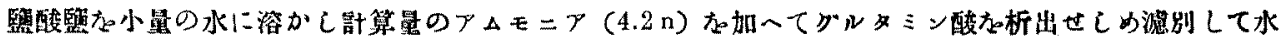
上り回再結す:-

F. P. $=212 \sim 214^{\circ} \mathrm{C}$ (急加㷫)

分 析： $N=(1) 9.60 \% ，(2) 9.38 \%$ 更妁 $9.49 \%$

許算数: $\mathrm{C}_{5} \mathrm{H}_{9} \mathrm{O}_{4} \mathrm{~N} \& \tau \tau \mathrm{N}=9.50 \%$

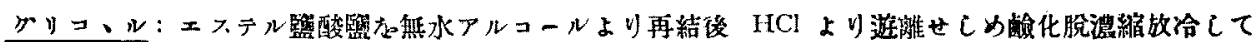
析出さろ結晶な别ち稀アルコールより三回再結す:-

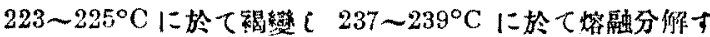

分 析: $\begin{array}{llll}\mathrm{N}=\text { (1) } 18.68 \% & \text { (2) } 18.85 \% & \text { 平均 } 17.76 \% \\ \mathrm{C}=\text { (1) } 31.73 \% & \text { (2) } 32.27 \% & \text { " } 32.00 \% \\ \mathrm{H}=\text { (1) } 6.83 \% & \text { (2) } 6.85 \% & \text { " } 6.84 \%\end{array}$

計算數: $\mathrm{C}_{2} \mathrm{H}_{5} \mathrm{O}_{2} \mathrm{~N}$ 巳て $\mathrm{N}=18.67 \% ; \mathrm{C}=31.98 \% ; \mathrm{H}=6.71 \%$

dーアラニン: 稀アルコールより反復再結す:- F.P. $=294 \sim 295^{\circ} \mathrm{C}$ (急加熱)

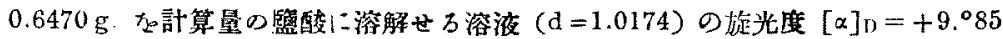

分 析： $N=$ (1) $15.82 \%(2) 15.68 \%$ 平均 $15.75 \%$

$\mathrm{C}=40.58 \% ; \quad \mathrm{H}=8.21 \%$

䂥算数： $\mathrm{C}_{3} \mathrm{H}_{7} \mathrm{O}_{2} \mathrm{~N} \& U \tau \mathrm{N}=15.73 \% ; \mathrm{C}=40.42 \% ; \mathrm{H}=7.93 \%$

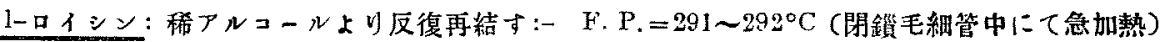

$0.5048 \mathrm{~g}$. 布 $25 \mathrm{ccm} .9$ 水に溶解せ万溶液 $(\mathrm{d}=1.0023)$ の旋兆度 $[\alpha]_{\mathrm{D}}=-8 .^{\circ} 78$

$0.7927 \mathrm{~g} .7 \mathrm{t} 15 \mathrm{ccm} .20 \% \mathrm{IICl}$ に溶解せ万溶液 $(\mathrm{d}=1.09798)$ の旋光度 $[\alpha] \mathrm{b}++14 .{ }^{\circ} 97$

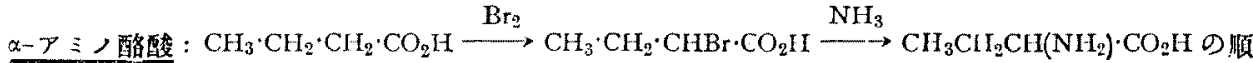
序で合成さろしのねアルコールより反復再結せり：-

F. P. $=303 \sim 304^{\circ} \mathrm{C}$ (閏鎖毛細管中にて㩊加热)

分 析： $\mathrm{N}=$ (1) $13.55 \% \quad$ (2) $13.53 \% \quad$ 平均 $13.54 \%$

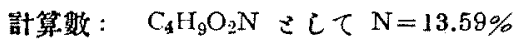

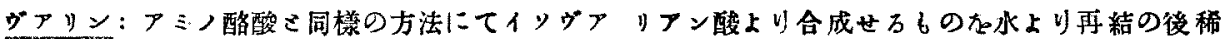

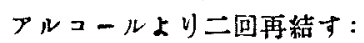

F. P. $=290 \sim 291^{\circ} \mathrm{C}$ (閉鎦毛細管中にて德加势)

分 析: $\mathrm{N}=(1) 12.11 \% \quad$ (2) $12.14 \%$ 平均 $12.12 \%$

部算数： $\mathrm{C}_{5} \mathrm{H}_{11} \mathrm{O}_{2} \mathrm{~N}$ として $\mathrm{N}=11.96 \%$

\section{2. アミノ酸水溶液の表面張力}


程々の濃度に於けるアミノ酸水溶液の比表面張力(Relative Oberflächenspannung) $\sigma=\frac{Z_{\mathrm{w}}}{Z} \frac{d}{d \mathrm{w}}$ を滴下法によりて求めたり但し $Z_{\mathrm{W}}$ 及びZは夫タ水又は溶液の滴數 にして、 Traube のスタラグモメーター（一滴の 1/20まで讀み取り得るすの）を

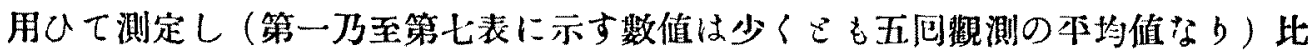
重 $\frac{d}{d_{\mathrm{w}}}$ の测定には Sprengel-Ostwald-Pyknometer を使用せ り

滴嫩測定溫度 : $18 . \pm 0.5^{\circ} \mathrm{C}$

比重測定溫喥 : $18 \pm 0.1^{\circ} \mathrm{C}$

$$
\text { 第 一 表 Glykokoll }
$$

(

0.00625

0.0125

0.025

0.05

0.1

0.2

0.4

0.8

1.2

$$
Z_{w}=63.80
$$

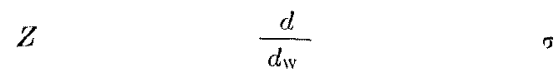

63.80

1.0002

1.000

63.77

1.0004

1.001

63.75

1.0007

1.001

63.86

1.0019

1.001

63.93

1.0031

1.001

64.00

1.0064

1.003

64.32

1.0127

1.004

64.73

1.0251

1.010

64.81

1.0373

1.021

$$
\text { 第三表 Alanin }
$$

$$
Z_{\mathrm{w}}=63.80
$$

賑
(Mol in $\mathrm{L}$.)

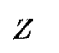

63.81

63.83

63.92

63.95

64.10

64.35

64.85

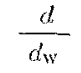

1.0004

1.0007

1.0014

1.0029

1.0057

1.0114

1.0230
5

1.000

1.000

0.9994

1.000

1.001

1.003

1.006

第三表 $\quad \alpha$-Aminobuttersäure

$$
Z_{\mathrm{w}}=63.80
$$

$$
\begin{gathered}
\text { 漂 } \\
\text { (Mol in L.) } \\
0.0125
\end{gathered}
$$

$z$

63.81

63.85

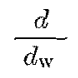

$$
\begin{aligned}
& 1.0002 \\
& 1.0006
\end{aligned}
$$

1.000

0.9997 


$\begin{array}{llll}0.1 & 64.05 & 1.0028 & 0.9989 \\ 0.15 & 64.22 & 1.0040 & 0.9975 \\ 0.2 & 64.35 & 1.0055 & 0.9969 \\ 0.3 & 64.54 & 1.0083 & 0.9968 \\ 0.5 & 65.04 & 1.0138 & 0.9945\end{array}$

\section{第四表 Valin}

$$
Z_{w}=63.80
$$

(Mol in I.)

0.0125

0.0238

0.0375

0.05

0.075

0.0954

0.15

0.2

0.25

0.3

0.4

0.5
$Z$

63.90

63.91

63.95

64.00

64.17

64,27

64.59

64.86

65.15

65.42

66.15

66.91

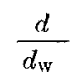

1.0003

1.0006

1.0009

1.0012

1.0020

1.0025

1.0039

1.0053

1.0068

1.0080

1.0108

1.0136 $\sigma$

0.9989

0.9988

0.9985

0.9981

0.9962

0.9952

0.9917

0.9889

0.9857

0.9830

0.9749

0.9665

\section{第五表 Leucin}

$$
Z_{\mathrm{w}}=63.80
$$

(Mol in L.)

0.0125

0.025

0.05

0.075

0.1

0.125

0.15
Z

64.03

64.18

64.70

65.19

65.80

66.42

67.25

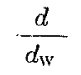

1.0002

1.0005

1.0012

1.0019

1.0027

1.0030

1.0038 $\sigma$

0.9966

0.9945

0.9873

0.9805

0.9722

0.9635

0.9523

第六表 Asparaginsäure

$$
Z_{\mathrm{w}}=63.80
$$

沄

0.0125 $z$

63.86

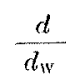

1.0007 $\sigma$

0.9998 


0.025
0.05

0.05

63.92

64.00
1.0014

1.0030

0.9995

1.000

第七表 Glutaminsäure

\begin{tabular}{|c|c|c|c|}
\hline \multirow[b]{2}{*}{$\begin{array}{l}\text { 㳻 } \\
(\mathrm{Mol} \text { in L. }\end{array}$} & \multicolumn{2}{|c|}{$Z_{w}=63.80$} & \multirow[b]{2}{*}{$\sigma$} \\
\hline & $Z$ & $\frac{d}{d \mathrm{w}}$ & \\
\hline 0.0125 & 63.82 & 1.0005 & 1.000 \\
\hline 0.025 & 63.95 & 1.0014 & 0.9990 \\
\hline 0.05 & 63.99 & 1.0028 & 0.9998 \\
\hline 0.07 & 64.02 & 1.0039 & 1.000 \\
\hline
\end{tabular}

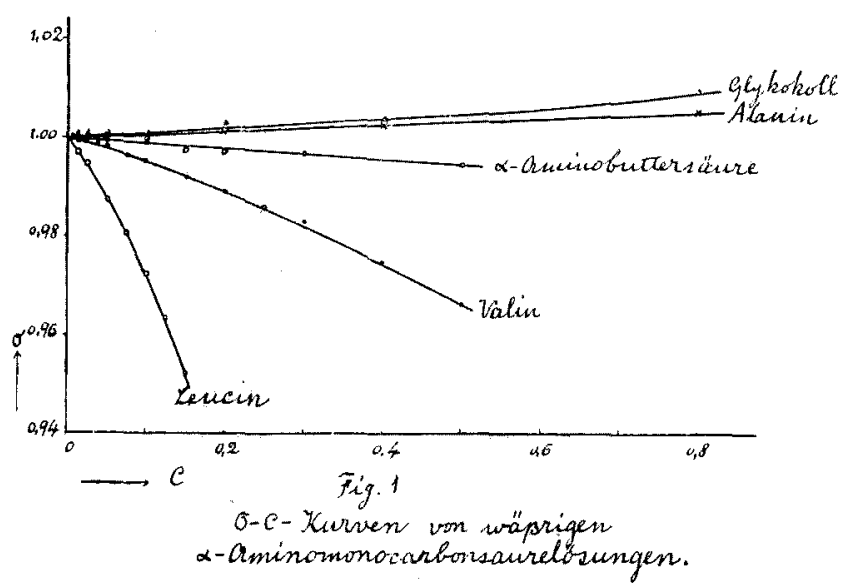

以上の結果を通覽する にアミノモノカルボン酸 は一般に相應せる脂肪酸 に比してその界面活性著 しく小にしてグリコ、ル アラニンの如きは却て僅 に水の表面張力を高さ然 れぞもとの同族列中 $\mathrm{CH}_{2}$ の增加に件ひ界面活性を 增す㥈 (Fig. 1. 參照) は 脂肪酸さ同㧼なり

次にアスバラギン酸及びグルタミン酸は何れも界面不活性なり（Fig. 2. 照）

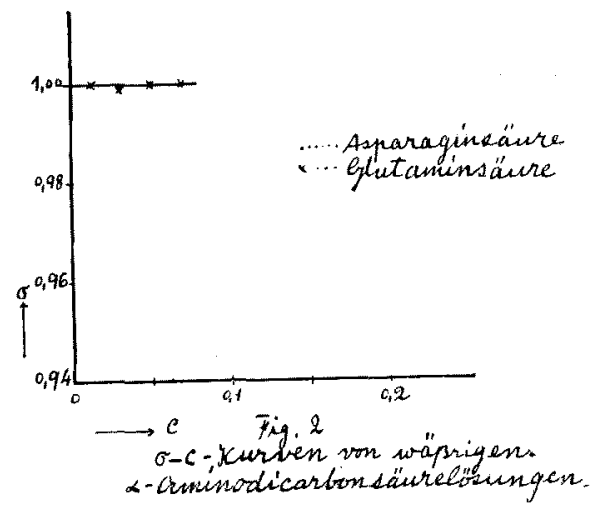

\section{3. アミノ酸の吸着}

吸着劑こしては $100 \sim 110^{\circ} \mathrm{C}$ に於て旡 量こなるまで乾燥せる骨炭（E. Merck. Carboanimalis Purissiums Siccus) を使用 せり約 $1.25 \mathrm{~g}$. の骨椃を共栓付エレンマ イヤーコルベン中に精密に科量しをり㱛 の其溫度を $18^{\circ} \mathrm{C}$ ざせるアミノ酸溶液 $25 \mathrm{ccm}$. 加人て $18 \pm 0.1^{\circ} \mathrm{C}$ の恆溫槽中 にて時々振盪し作ら20分間保ちてる倦 エナガラス製濾器を用ひて手早く濾過す但し最初の港液約 $5 \mathrm{ccm}$. は之等を放童 


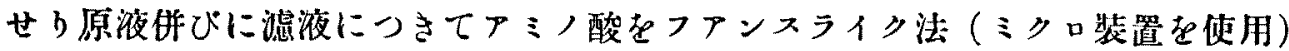
に侬り定量し雨者の差より吸着されたるアミノ酸量を算出せb

第八表 Glykokoll

\begin{tabular}{|c|c|c|}
\hline \multicolumn{2}{|c|}{ 涨 $f^{t}$ (Mol in $\mathrm{I}$. .) } & \multirow{2}{*}{ (Millimol/g. Kohle) } \\
\hline 吸着前 & 吸着後 & \\
\hline 0.025 & 0.0247 & 0.005 \\
\hline 0.05 & 0.0495 & 0.010 \\
\hline 0.1 & 0.0996 & 0.009 \\
\hline
\end{tabular}

第九表 Alanin

\begin{tabular}{lcc}
\multicolumn{2}{c}{ 濃度 (Mol in I.) } & $\begin{array}{c}\text { 吸着量 } \\
\text { (Millimol/g. }\end{array}$ Kohle) \\
0.0125 & 吸着後 & 0.013 \\
0.025 & 0.0118 & 0.015 \\
0.0375 & 0.0242 & 0.024 \\
0.05 & 0.0363 & 0.028 \\
0.075 & 0.0486 & 0.031 \\
0.1 & 0.0734 & 0.038
\end{tabular}

第十表 $\alpha$-Aminobuttersäure

$$
\frac{x}{m}=1.18 \mathrm{C}^{0.34}
$$

濃度 $(\mathrm{Mol}$ in $\mathrm{L}$.)

$\begin{array}{lc}\text { 吸着前 } & \text { 吸者後: C } \\ 0.0125 & 0.0110 \\ 0.025 & 0.0227 \\ 0.0375 & 0.034 ! \\ 0.05 & 0.0459 \\ 0.075 & 0.0684 \\ 0.1 & 0.0915 \\ 0.15 & 0.1386 \\ 0.2 & 0.1868\end{array}$

吸着量： $x / m$ (Millimal/g. Kohle)

$\begin{array}{lr}\text { 诲驗数 } & \text { 計算數* } \\ 0.029 & 0.0267 \\ 0.046 & 0.0491 \\ 0.067 & 0.0691 \\ 0.082 & 0.0887 \\ 0.131 & 0.1239 \\ 0.169 & 0.1583 \\ 0.227 & 0.2243 \\ 0.263 & 0.2883\end{array}$

*表の上に記したる式 $x / m=1.18 \mathrm{C}^{0.84}$ によりて計算さ万数值なり 以下之に準す 


\section{第十一表 Valin*}

$$
\frac{x}{m}=1.33 \mathrm{C}^{0.541}
$$

墁度 (Mol in L)

\begin{tabular}{|c|c|}
\hline 吸着前 & 吸等嵝: C \\
\hline 0.00625 & 0.0042 \\
\hline 0.0125 & 0.0088 \\
\hline 0.025 & 0.0176 \\
\hline 0.0375 & 0.0281 \\
\hline 0.05 & 0.0386 \\
\hline 0.075 & 0.0601 \\
\hline 0.0954 & 0.0792 \\
\hline 0.15 & 0.1291 \\
\hline 0.2 & 0.1744 \\
\hline 0.3 & 0.2684 \\
\hline
\end{tabular}

*此惯羷には $1.23 \mathrm{~g}$ ，骨宸加使用せり
吸着量: $x / m$ (Millmol/g. Kohle)

\begin{tabular}{|c|c|}
\hline 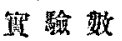 & 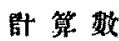 \\
\hline 0.041 & 0.0643 \\
\hline 0.076 & 0.1033 \\
\hline 0.150 & 0.1495 \\
\hline 0.190 & 0.1925 \\
\hline 0.231 & 0.2287 \\
\hline 0.303 & 0.2906 \\
\hline 0.335 & 0.3373 \\
\hline 0.426 & 0.4394 \\
\hline 0.518 & 0.5170 \\
\hline 0.643 & 0.6529 \\
\hline
\end{tabular}

\section{第十二表 Leucin}

$$
\frac{x}{m}=1.87 \mathrm{C}^{0.422}
$$

骨岸 量

$$
\text { (g.) }
$$

1.2524

0.3131

1.2594

0.3143

1.2296

0.3094

1.2570

0.3145

1.2560

0.3127

1.2510

0.3162

1.2530

1.2548

浱度
0.00625
0.0125
$\prime \prime$
0.025
$\prime \prime$
0.05
$\prime \prime$
0.075
$\prime \prime$
0.1
$\prime \prime$
0.125
0.15

浱度 (Mol in L.)

\begin{tabular}{|c|c|}
\hline 䗝 驗 數 & 計 算 叒 \\
\hline 0.095 & 0.1203 \\
\hline 0.160 & 0.1858 \\
\hline 0.164 & 0.1858 \\
\hline 0.257 & 0.2597 \\
\hline 0.281 & 0.2809 \\
\hline 0.376 & 0.3611 \\
\hline 0.423 & 0.4149 \\
\hline 0.519 & 0.4981 \\
\hline 0.529 & 0.5210 \\
\hline 0.571 & 0.6007 \\
\hline 0.600 & 0.6084 \\
\hline 0.708 & 0.6813 \\
\hline 0.661 & 0.6826 \\
\hline 0.733 & 0.7457 \\
\hline
\end{tabular}

着前吸着啳:C

昅在量: $x / m$

第十三表 Asparaginsäure

$$
\frac{x}{m}=2.18 \mathrm{C}^{0.67}
$$

䁲度( Mol in L.)

$\begin{array}{cc}\text { 吸着前 } & \text { 吸着後:C } \\ 0.00625 & 0.0087\end{array}$

吸着星: $x / m$ (Milimol $/ \mathrm{g}$. Kohle) 


0.0125
0.025
0.04
0.05

$\begin{array}{lll}0.0080 & 0.090 & 0.0858 \\ 0.0179 & 0.141 & 0.1472 \\ 0.0292 & 0.214 & 0.2043 \\ 0.0380 & 0.239 & 3.2438\end{array}$

\section{第十四表 Glutaminsäure}

$$
\frac{x}{m}=2.53 C^{0.554}
$$

\section{骨宸量}

(g.)

1.2536

0.3112

1.2510

0.3109

1.2562

0.3152

1.2583

0.3124

1.2537

0.3103

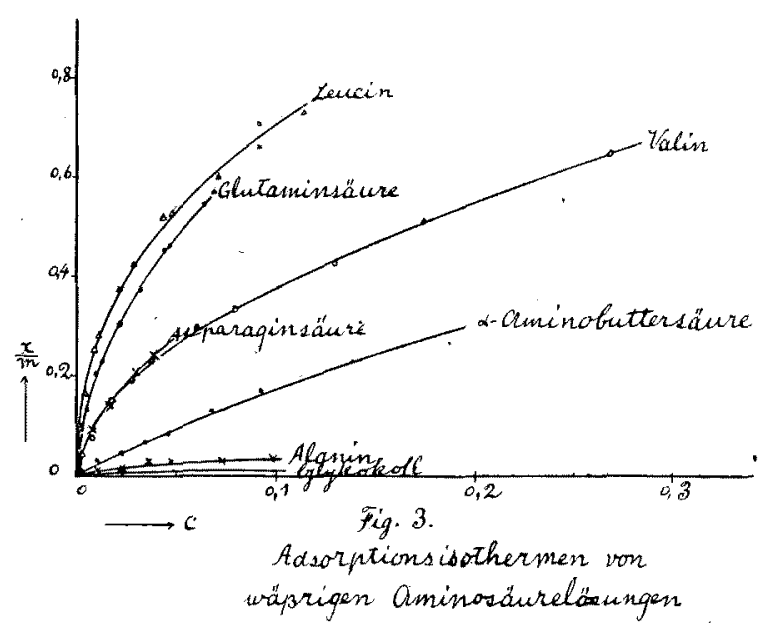

\begin{tabular}{|c|c|}
\hline \multicolumn{2}{|c|}{ 濃笭( } \\
\hline 吸 着 前 & 吸着後: C \\
\hline 0.00625 & 0.0026 \\
\hline$"$ & 0.0040 \\
\hline 0.0125 & 0.0060 \\
\hline " & 0.0100 \\
\hline 0.025 & 0.0134 \\
\hline " & 0.0213 \\
\hline 0.05 & 0.0313 \\
\hline$" \prime$ & 0.0444 \\
\hline 0.07 & 0.0464 \\
\hline I & 0.0 \\
\hline
\end{tabular}

吸着量: $x / m$ (Millimol/g. Kohie)

以上の結果を綜合するに一 般にナミノ酸の骨炭による吸 着度は相鱀脂肪酸のそれに比 して著しく低くけれごもその 同族列に於て $\mathrm{CH}_{2}$ の增加に 伴ひて睤大する點は是と軌を 一にす（Fig. 3. 垒照） いま Endkonzentration = $0.1 \mathrm{Mol} / \mathrm{L}$.に於けるアミノモ ノカルボン酸の吸着量を圖上 に求めて是こ濃度 $=0.1 \mathrm{Mol} / \mathrm{L}$.

に於けるその比表面張力こを次表に於て比較對照せむに

第十五表

$\boldsymbol{P}>$ 酸

Gylykokoll

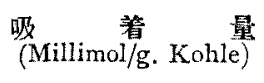

0.01
此表酸張力

$\left({ }^{6} \mathrm{H}_{2} \mathrm{O}=1\right)$

1.001 


$\begin{array}{lll}\text { Alanin } & 0.03 \tilde{5} & 1.000 \\ \alpha-\text { Aminobuttersäure } & 0.17 & 0.9989 \\ \text { Valin } & 0.39 & 0.995^{*} \\ \text { Leucin } & 0.71 & 0.9722\end{array}$

*阔上に求七

師ちアミノモノカルボン酸に於てはその吸着と界面活性との間に明に平行關係 を認む但しグリコ、ル及びアラニンは界面不活性なれご極めて僅に败着せらるっ は泩日に值す

同樣にアスバラギン酸及びグルタミン酸も亦界面不活性なるにかつわらずかな

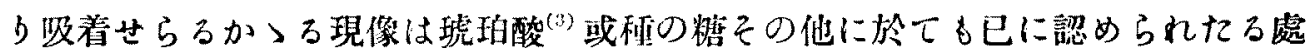
なり

第十二及び第十四表は口イシン又はダルタミン酸の水溶液 $25 \mathrm{ccm}$.に對し $1.25 \mathrm{~g}$.

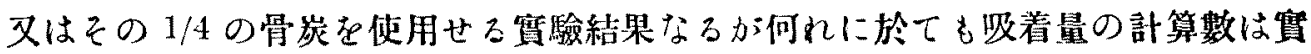
驗數こはよく一致す換言すれば何れるこの吸着は骨炭の使用量に關係なく夫タ同 一の Adsorptionsisothermeによbて表現し得らる他のアミノ酸に於てる恐らく同 樣なるくし (Powlow: Kolloid Z., 35, 221 (1924) 照)

附記

本研究に使用せるアミノ酪酸は當貨驗室に於て長風善助君の合成せるものなる （炤和四年十二月，盛岡高等農林學校農藝化學實羷窒に笒て）

\section{文獻}

(1) Fermentforschung: 2,74(1917); 2, 151 (1918); Kolloid Z., 27, 49 (1920).

(2) Plimer: The Chem. Cunstitution of the Proteins. 2 nd Ed, 24 (1912).

(3) Freundlich: Kapillarchemie, 3. Auf,, 268 (1923). 